\title{
Can the International Criminal Court Deter Atrocity?-CORRIGENDUM
}

\author{
Hyeran Jo and Beth A. Simmons
}

doi:10.1017/S0020818316000114. Published by Cambridge University

Press, 8 July 2016.

A coding error resulting in duplicate observations in rebel group data was discovered in an article by Jo and Simmons ${ }^{1}$. Thanks to Dr. Michael Broache at the University of Tampa for discovering the error. The error relates to the findings on rebel deterrence only; none of the findings for government actors are affected by the error. In the original article we concluded that "Neither ICC RATIFICATION (Model 1) nor DOMESTIC CRIME STATUTE (Model 3) appears to reduce rebel civilian killing." This claim is sustained. We also wrote that "However, even rebel groups appear to respond to ICC ACTIONS (Model 2)." This conclusion is also sustained, although somewhat less significantly. Finally, we wrote that "Rebels do not respond to legal change alone; they are much more impressed with action."2 This conclusion is also sustained, but correcting the error shows that the ratification of the ICC may be associated with increased violence among rebel groups, which differs from our initial conclusion of "no effect" and is contrary to theoretical expectations of prosecutorial deterrence. Overall, corrected results still suggest that if rebel prosecutorial deterrence exists (and we agree that the results, when corrected, are marginally significant), deterrence flows from ICC actions, and not from ratification of ICC statutes.

With respect to the social deterrence of rebel groups, our conclusion that there is "some evidence of social deterrence for a particular class of rebel groups"3 is sustained, in that the triple interaction of SECCESSIONIST* DISCIPLINE* POST-ICC is essentially unchanged. The triple interaction was not flagged as statistically significant in the original version, and the result is approximately the same with the correction (i.e., expected direction, though not statistically significant). To be clear, both the original and the corrected findings show that for rebel groups, relative strength and government behavior are the most consistent predictors of rebel intentional killing.

The corrected data for the rebel analysis and the corrected table on rebel deterrence can be found here. The error is the complete responsibility of the coauthors.

1. Jo and Simmons 2016.

2. Ibid., 468.

3. Ibid. 
TABLE 3. ICC effect on civilian killing by rebel groups (Corrected Table)

\begin{tabular}{|c|c|c|c|c|c|c|}
\hline & $\begin{array}{l}\text { Corrected Model } 1 \\
\text { ICC ratification }\end{array}$ & $\begin{array}{l}\text { Corrected Model } 2 \\
\text { ICC actions }\end{array}$ & $\begin{array}{l}\text { Corrected Model } 3 \\
\text { ICC complementarity }\end{array}$ & $\begin{array}{l}\text { Corrected Model } 4 \\
\text { All ICC effects }\end{array}$ & $\begin{array}{l}\text { Corrected Model } 5 \\
\text { Social deterrence } \\
\text { without ICC }\end{array}$ & $\begin{array}{l}\text { Corrected Model } 6 \\
\text { Social deterrence } \\
\text { with ICC }\end{array}$ \\
\hline ICC RATIFICATION & $\begin{array}{l}0.534 * * \\
(0.229)\end{array}$ & & & $\begin{array}{l}0.560^{* *} \\
(0.237)\end{array}$ & & \\
\hline ICC ACTIONS & & $\begin{array}{c}-0.113 * \\
(0.058)\end{array}$ & & $\begin{array}{l}-0.123^{* *} \\
(0.059)\end{array}$ & & \\
\hline DOMESTIC CRIME STATUTE & & & $\begin{array}{l}-0.072 \\
(0.156)\end{array}$ & $\begin{array}{c}-0.097 \\
(0.165)\end{array}$ & & \\
\hline RULE OF LAW & & & $\begin{array}{c}-0.229 * \\
(0.125)\end{array}$ & $\begin{array}{r}-0.214^{*} \\
(0.126)\end{array}$ & & \\
\hline SECESSIONIST REBELS & & & & & $\begin{array}{c}-0.275^{*} \\
(0.160)\end{array}$ & $\begin{array}{r}-0.557 \\
(0.472)\end{array}$ \\
\hline SECESSIONIST*DISCIPLINE* POST ICC & & & & & & $\begin{array}{c}-0.171 \\
(0.130)\end{array}$ \\
\hline SECESSIONIST*DISCIPLINE & & & & & & $\begin{array}{c}0.193 \\
(0.219)\end{array}$ \\
\hline DISCIPLINE*POST ICC & & & & & & $\begin{array}{l}0.342 * \\
(0.207)\end{array}$ \\
\hline DISCIPLINE & & & & & & $\begin{array}{c}-0.050 \\
(0.149)\end{array}$ \\
\hline POLITICAL REGIME TYPE & $\begin{array}{r}-0.005 \\
(0.012)\end{array}$ & $\begin{array}{l}-0.003 \\
(0.012)\end{array}$ & $\begin{array}{c}0.017 \\
(0.017)\end{array}$ & $\begin{array}{c}0.016 \\
(0.017)\end{array}$ & $\begin{array}{c}0.002 \\
(0.013)\end{array}$ & $\begin{array}{c}0.001 \\
(0.013)\end{array}$ \\
\hline POST ICC REGIME & $\begin{array}{r}-0.047 \\
(0.143)\end{array}$ & $\begin{array}{l}0.265 \\
(0.165)\end{array}$ & $\begin{array}{c}0.087 \\
(0.139)\end{array}$ & $\begin{array}{c}0.207 \\
(0.171)\end{array}$ & $\begin{array}{l}0.050 \\
(0.134)\end{array}$ & $\begin{array}{r}-0.492 \\
(0.411)\end{array}$ \\
\hline REBEL STRENGTH & $\begin{array}{l}0.320^{* * * *} \\
(0.111)\end{array}$ & $\begin{array}{l}0.341 * * * \\
(0.110)\end{array}$ & $\begin{array}{l}0.261 * * \\
(0.118)\end{array}$ & $\begin{array}{l}0.261^{* *} \\
(0.118)\end{array}$ & $\begin{array}{l}0.323 * * * \\
(0.110)\end{array}$ & $\begin{array}{l}0.328^{* * * *} \\
(0.113)\end{array}$ \\
\hline GOVERNMENT KILLING & $\begin{array}{l}0.000^{* * * *} \\
(0.000)\end{array}$ & $\begin{array}{l}0.000 * * * \\
(0.000)\end{array}$ & $\begin{array}{l}0.000^{* * *} \\
(0.000)\end{array}$ & $\begin{array}{l}0.000^{* * *} \\
(0.000)\end{array}$ & $\begin{array}{l}0.000^{* * * *} \\
(0.000)\end{array}$ & $\begin{array}{l}0.000 * * * \\
(0.000)\end{array}$ \\
\hline OBSERVATIONS & 1,396 & 1,396 & 1,396 & 1,396 & 1,396 & 1,396 \\
\hline NUMBER OF REBEL GROUPS & 260 & 260 & 260 & 260 & 260 & 260 \\
\hline
\end{tabular}

Notes: Standard errors in parentheses are in parentheses. The dependent variable is the count of civilians killed by rebel groups. Results are based on a negative binomial panel analysis with random effects. Constants are suppressed. $* p<.10 ; * * p<.05 ; * * *<.01$. 


\section{Reference}

Jo, Hyeran, and Beth A. Simmons. 2016. Can the International Criminal Court Deter Atrocity? International Organization 70 (3):443-75. 